\title{
Homo Economicus Meets Homo Religiosus: A Collaborative Undergraduate Course in Economics and Religion
}

\author{
Feler Bose \\ Alma College \\ bose@alma.edu
}

\author{
Kathryn D. Blanchard \\ Alma College \\ blanchard@alma.edu
}

\begin{abstract}
AB STRACT: This paper describes an interdisciplinary undergraduate course exploring multiple intersections of economics and religion using a variety of textual sources, exercises, and teaching methods from both fields. We conclude that such a course can be valuable for both majors and non-majors. Economics majors may gain a greater awareness of the philosophical underpinnings and ethical implications of their social science, while non-economists may gain an appreciation for the many ways in which the economic way of thinking affects and can be applied to aspects of their everyday lives. While this course was taught in a largely secular school with Presbyterian roots, the syllabus can easily be adjusted for a more evangelical college.
\end{abstract}

\section{INTRODUCTION}

In modern graduate education, the dominant trend has been to shape scholars and future professors who are experts in a very narrow slice of disciplinary knowledge. According to this longstanding tradition, economists are economists and theologians are theologians, and never the twain shall meet. Scholars then carry these mental "silos" with them into their classrooms at the undergraduate level.

The 21st century world, however, is increasingly calling upon colleges and universities to adjust their academic models to better fit the new global realities into which students graduate, go to work, and live their lives. The discipline of economics is no exception; even those heavily steeped in the economic way of thinking are now expected to be able to address multiple aspects of, and changes in, human social and individual life. These include globalizing markets, as always, but also technology, environmental concerns, gender roles and family structures, terrorism and militarism, education, and even religious sensibility. Taking a collaborative and interdisciplinary approach to teaching economics for undergraduates is one possible step toward exposing more non-majors to the economic way of thinking, as well as toward inspiring more creative and interdisciplinary thinking among economic specialists.

The authors, an economist and a Christian theologian, taught a collaborative course in economics and religion in a secular liberal arts college with Presbyterian heritage. In departments large enough to afford elective courses, this course could be adapted for an explicitly Christian context, whether as a team-taught effort or for an economist teaching alone. Alternatively, aspects of the course could be incorporated into broader economics curricula. In the following sections, we discuss the importance of collaboration and interdisciplinary teaching, as well as offer a rationale for why interdisciplinary work for economists can include religion. We then discuss the specifics of our course, Economics and Religion, and evaluate the course from faculty and student perspectives. Finally, we provide pointers as to how this course could be adapted for an evangelical college.

\section{WHY COLLABORATION?}

The goal of interdisciplinary undergraduate teaching, like the goal of all teaching, is to enhance students' learn- 
ing. In the past decade or so, educators have begun to stress the value of interdisciplinarity in undergraduate pedagogy. A recent argument by the American Association of Colleges and Universities (AAC\&U) states that an effective education should result in graduates who have "knowledge of human cultures and the physical and natural world"; "intellectual and practical skills," such as critical thinking; "personal and social responsibility," including civicmindedness; and "integrative learning" that allows them to apply knowledge to new situations ("College Learning for the New Global Century: A Report from the National Leadership Council for Liberal Education and America's Promise," 2007, p. 3). Such habits of mind do not happen by themselves, however; students' minds must be trained in this direction through appropriate pedagogical strategies.

Collaboration is one strategy that can help professors move in this direction. It can be difficult for an individual professor with training in one particular discipline to sacrifice "content" in the interest of interdisciplinarity, especially in introductory courses where the pressure to "cover" every basic concept can be very great. Nevertheless, content coverage may not have the overall outcomes we want for 21st-century college graduates. The Boyer Report on Reinventing Undergraduate Education argued, "Many students graduate having accumulated whatever number of courses is required, but still lacking a coherent body of knowledge or any inkling as to how one sort of information might relate to others"(Kenny, 1998, p. 6). Students, in other words, need help connecting their study of economics to their understandings of the world more broadly. The ultimate point is not merely to understand basic principles, but rather to make sense of how such principles fit into the whole of their education (Davis, 1995, p. 42-43).

Another reason to think about collaboration has to do with pedagogical style. Economists, as a group, have tended toward traditional lecture models of teaching (Jensen \& Owen, 2003, p. 300). Having not been shaped in an atmosphere of experimental pedagogy, economists may find it difficult to branch out. Excellent teaching, however, may demand such stretching on our part. One economics study suggests that, among high-achieving students:

Overall... students prefer classes that contain less lecture and more discussion. However, our results also suggest that students - even various subsamples of good students — respond differently to techniques such as group problem-solving, participation, and the use of exams as a means of evaluation. Using a variety of teaching techniques may be the most successful way of appealing to the broad range of learning styles adopted by good students (Jensen \& Owen, 2003, p. 323).

While professors of theology and religious studies can also easily fall into the "sage on the stage" model of teaching, the nature of the material (questions about ethics, sacred texts, and even the meaning of life) lends itself to a strong culture of discussion-based learning, particularly among newer scholars, and particularly in small classes. Collaboration can also be a way of reaching new audiences, specifically by addressing topics not usually explored at a generalist or introductory level.

Economists themselves have also begun experimenting in the interest of promoting the economic way of thinking among non-majors; some have tried new pedagogies of late, moving beyond lecture and multiple-choice exams to incorporate discussion, essays, and even film (Leet \& Houser, 2003). One economist argues that, in many cases, "the most interesting courses offered in the discipline are taught to a minority of students," and thus, "developing courses that incorporate the various elements of economic fields at an introductory level can increase enrollment in economics classes and overall participation in the major. These goals are relevant to the field of economics because research has shown that only 40 percent of college graduates are exposed to economics courses during their college careers" (CavigliaHarris, 2003). If economists want to reach a broader segment of the student body, one way to do that is to bring economics to them wherever they are; this may involve working with non-economists and/or departing from their usual teaching methods. While a certain amount of basic economics content may be lost, the marginal benefits can outweigh the marginal costs for most students.

\section{WHY RELIGION?}

There are a large number of possible avenues for fruitful interdisciplinary conversation that economists could pursue. One economist argues for a deliberate reintegration of economic methods with methods from the other social sciences (Evensky, 2004), but there is no reason interdisciplinary teaching needs to stop there. Economics paired with religion is another way that departments of economics can engage the real world issues that students and graduates deal with on an almost daily basis. In some respects, such a combination simply takes economics back to its own roots; the American Economic Association was, after all, founded largely by Protestant Christian "social gospel” thinkers who, 
in 1885 , sought to avail themselves of scientific methods in order to bring about the kingdom of God on earth. After a decade or so, however, the increasingly pluralistic association came to see the religious connection as "unnecessary" to its emerging science (Nelson, 2001, p. 41-42). A.M.C. Waterman pinpoints the split between Christianity and political economy even earlier, around 1820, following the Reverend Malthus' dismal pronouncements on population growth, misery, and vice (Waterman, 2001).

Despite economists' traditional lack of interest in religion as either subject or plumb line ${ }^{1}$, theologians and scholars of religion have, for their part, not lost an interest in economics and have rarely shied away from addressing economic and social concerns. Ancient religious founders and figures, almost without exception, have considered issues of livelihood, wealth, poverty, and consumption well within religion's purview. Medieval and modern religious thinkers have taken their founders' teachings and sought to apply them to whatever economic realities and changes they faced in their own times and places. Early Western economic thought developed alongside and in response to important Christian thinkers like Aquinas, Luther, Calvin, and Wesley; ${ }^{2}$ and today's Islamic banking system, while sharing some of Western economics' medieval foundations, is an approach all its own. ${ }^{3}$

An alternative intersection between religion and economics occurs when economists approach religion itself as an economic phenomenon (known as "economics of religion"). Such an approach can be traced to Adam Smith. In his Wealth of Nations, he argued that religion could be dangerous if the state favored one church over another, thereby disrupting individual behaviors and market mechanisms; the best way to deal with religious conflict, he argued, was to have the state refrain from interfering in the religious market in any way beyond the most basic protections. This would result in a free market for religion with hundreds or thousands of competing sects, which would represent a net gain for individuals and liberal society (Smith 1981, [1776]). Two centuries after Smith, following insights from other areas of economics like public choice, public finance, household production, and human capital models and from the various empirical data available on the issue of religion, economists began to write seriously again about religion as an economic phenomenon, the first paper being that of Azzi and Ehrenberg (1975). ${ }^{4}$ Part of the reason for the huge gap in time was the modern Enlightenment notion that religion was irrational and, therefore, outside the scope of economics and that it would inevitably decline with the advancement of science and technology. This so-called "seculariza- tion thesis" enjoyed long popularity in the social sciences (Iannaccone, 1998, p. 1468), but it has more recently fallen out of favor as even its best-known proponents have acknowledged that 21 st century facts and experience do not support theory (Berger, 1999). Since religion does not seem to be disappearing despite modernization, the idea that people might be religious for rational reasons helps propel the notion that religion can be an important area of inquiry for economists.

Economists studying religious behavior have now much to say about religious markets such as the demand for religion, religious supply, giving behavior, religion based terrorism/extremism, religious re-affiliation, optimal firm sizes, macro religious markets, and religion and economic development. Further, the scope of economics of religion is even broader when one looks at proposals welcomed by the Association for the Study of Religion, Economics, and Culture (a new organization). They includes:

- Religious markets, competition, monopoly, and regulation

- Economic growth, development, poverty, and inequality

- Social networks, and social/spiritual/religious capital

- Extremism, conflict, sectarianism, and religious persecution

- Application of experimental, simulation, and computational methods

- Beliefs, attitudes, doctrines, norms, and values, especially in the context of evolutionary theory

- Labour markets, management of volunteering and governance in not-for-profit organizations

- Institutions, organizations, congregations, and denominations

- Trends in participation, attendance and commitment to religious organizations

- Conversion, switching, proselytizing, and the marketing of religion

- Religious giving, philanthropy, and church finances

- Demography, fertility, family, marriage, and gender

- Education, human capital, health, and happiness

- Race, ethnicity, and discrimination

- Politics, public choice/finance, church-state issues, and the law

Thus, while it would be inappropriate to force religion and economics into a single mold, it is clear that any artificial separation between the academic study of these two topics is an historical relic that no longer serves our students well, particularly in liberal arts contexts. 


\section{THE COURSE}

This particular course grew organically from the interests of the two faculty members. One of us is an economist whose research interests have been mainly in the intersection of economics, law, religion, and politics. The other is a Christian ethicist whose research has included a focus on theological understandings of economics and human freedom. Our course, Economics and Religion, was cross-listed three ways in economics, religious studies, and the Honors Program; it met twice a week for 80 minutes each. The two 200-level courses (Honors and Religious Studies) had no economics or religious studies prerequisites. The economics course, however, was a 300-level course; as such, it required the student to have already completed a principles course and evaluated students' written work according to higher expectations. This resulted in a mix of approximately 18 students that included first-years and seniors, economics majors, political science majors, religious studies minors, Honors Program students, and students taking the course simply to fulfill a distributive requirement in the humanities. The format was a combination of lecture and discussion, and though the instructors took turns leading class, both professors were present at almost every meeting.

The outline of the 14-week course began with readings and discussions related to the questions "What is economics?" and "What is religion?" (see appendix for details). Our goals here were to introduce the topics to students who were studying economics and/or religion for the first time, as well as to raise awareness about the fact that the answers to such questions are not self-explanatory and are, therefore, worthy of reflection and analysis. We introduced the idea that the texts we would encounter during the term, despite their differences in method, would constitute a broad argument about human nature. Although this is beginning to change, economics has traditionally been a body of literature that presented (or made the assumption of) the human being as homo economicus - the person who makes rational choices based on self-interest, bound by constraints. The academic study of religion, in contrast, has traditionally tended to approach analysis from the assumption of human beings as homo religiosus - the person who seeks meaning and purpose in life and who creates sacred spaces, times, rituals, ethical practices, and/or stories that help support that search for meaning (Eliade, 1959). ${ }^{6}$

From there we moved on to readings regarding the economics of religion, applying economic perspectives to "the domain of conventional religious beliefs, behavior, and institutions" (Iannaccone, 2010, p. 2). The course introduced students to ways in which the rational choice approach has been applied to religious behavior at the individual, group, and national levels, exploring questions such as: Why do people convert (religious switching)? Why do some religions grow rapidly while others decline? How is religious commitment affected by factors like age, income, or sex? What is the role of religion in extremism? How do people give to religion? What is the optimal firm (church or congregation) size and what competitive strategies should firms use? To answer these questions, we included a number of works by Laurence Iannaccone (an economist) and Rodney Stark (a rational choice sociologist), two of this approach's major proponents. ${ }^{7}$

We also included articles that took an alternative approach to the study of economics and religion that presented "economics as religion"(Nelson, 2001), or more precisely, as a particular school of theological thought with its own assumptions, ethical practices, high priests, and doctrinal beliefs. Selections for this approach included some classic writings from the history of economic thought, including authors such as Jeremy Bentham, Adam Smith, and Frank Knight. The point of such readings was to highlight the sharp contrast between the understandings of human nature that underlie both economic science and the academic study of religion, while at the same time asking students to analyze and clarify their own understandings.

In the final section of the course, we looked at current events and issues as a means of exploring the question, "Does economics shape religion or does religion shape economics?" Again, the goal here was not simplistically to force students into choosing one side of the argument or the other. Our goal was rather to familiarize them with the approaches inherent in each discipline and to get them to think critically about such questions in a way that would be useful to them later, not only in their liberal arts curriculum but also in life. All the assignments for the course including several homework problems, ${ }^{8}$ three short essays on course texts, in-class participation, and a group presentation $^{9}$ - were designed with the same purpose in mind. Other aspects of the course included watching movie clips (from Tom Shadyac's Bruce Almighty, (2003)) or whole films (Danny Boyle's Millions, (2004)) and relating them to theory they had learned. The 300-level economics students had the additional requirement of making a field trip to a religious group they were unfamiliar with and using their observational skills and knowledge learned in the class to analyze the religious group in a class presentation.

While the course was strong in exposing students to the "economics of religion" and "economics as religion" approaches, we were unable to include a section on "reli- 
gious economics," where theological views are used to analyze and critique economic action. In other words, there was no explicit coverage of such topics as Islamic economics, Buddhist economics, or Catholic social thought. This was mainly due to the lack of time and it reflects the ongoing reality that, although there are many theologians and religious scholars working seriously on questions of economics, their writings are often not of interest to economists, who tend to draw a strong methodological boundary between what they see as the "facts" of social science and the "values" of the humanities (Iannaccone, 1998, p. 1466).

\section{STUDENT AND FACULTY EVALUATION OF THE COURSE}

This course had mixed results from both the professors' and the students' points of view. Some goals were met while others remained elusive; some students produced exceptionally good work while others struggled to meet requirements. In our anonymous student evaluations, we received a variety of comments, ranging from those who saw it as one of the best courses they had ever had to at least one who felt it was a waste of his or her time. ${ }^{10}$

Most of the negative comments seemed to rest upon the fact that some (most likely the first- and second-year) students felt unprepared to meet the requirements of the course. Examples of such comments include that "assignments were unclear/vague before we received feedback from them"; "class discussions were helpful, but sometimes it was difficult to participate"; "I felt pretty lost with some of the econ stuff 11 "; or "I spent a lot of time reading things that I didn't really understand and that were somewhat inapplicable to my life." (This may also have been due in part to an unusually heavy workload - a risk with teamtaught courses where both teachers have texts they consider absolutely necessary.) In other words, students were sometimes uncomfortable with aspects of the course that were out of their intellectual comfort zones - whether their comfort zones included writing essays, participating in discussion, solving economics problems, or reading and making connections among varied and complex texts. To some extent, this discomfort is perhaps to be expected of any interdisciplinary course. It was unclear from students' evaluations whether they self-identified as "religious" or not, and whether or not this made a difference to their feelings about the course.

At the positive end of the spectrum, we also had several (most likely junior and senior) students who felt they had learned a great deal from the course. One wrote, "It made me look behind my own values and beliefs to see how they fell into a larger picture of religion, economics, and even politics." Another wrote, "[T] his was one of the most worthwhile classes I have taken thus far. Once again, it allowed me to view things from a different perspective. Interesting material as well." Perhaps the most satisfying comment was that "the best part about this course was its overwhelmingly liberal-artsy nature. Courses like these are what 'liberal arts' means — thinking critically in a new way, connecting dots that others leave untethered. Fascinating!!”

While it is likely that most students' comments say more about them than about the professors or the course itself, ${ }^{12}$ in general these comments were consistent with the impression the faculty members had throughout the term. Because we had such a motley crew of students from different classes and majors, with vastly different skill sets, it was clear almost from the beginning that certain students were well prepared to make the most of the course while others had a great deal of trouble getting a handle on the subject matter. This latter group (first-years and sophomores, especially) would have benefited from having an introductory course in economics, religious studies, or both. Administrative pressure to fill classes, however, makes it particularly difficult for team-taught courses in small departments to add prerequisites that might reduce enrollment numbers.

In short, the biggest problems we faced were related to a lack of focus in our course design. While in large universities it may be possible to require prerequisites in economics for an interdisciplinary course like this one, it is necessary in smaller schools for professors to be more deliberate about introducing the major concepts of each discipline before embarking upon the critical thinking that is the ultimate goal of such a course.

\section{COURSE ADAPTATION}

While this course was taught in a secularized protestant liberal arts college, it could easily be adapted for an evangelical college or to be taught by an economics professor alone. Iannaccone writes that Christian schools should "welcome the economics of religion as a valuable addition to their teaching portfolios." He notes that a course in economics of religion allows for the "integration of religious faith and secular rigor" (2010, p. 6). Therefore, the course as is and with some modifications could continue to match the "rigor of high-quality secular schools but maintain meaningful ties to faith" (Iannaccone, 2010, p. 9). See the 
appendix for additional resources that could be used to modify the syllabus presented in this paper.

However, as the field of economics of religion continues to receive mainstream recognition (it now has its own Journal of Economic Literature code), the tendency of the field/course is to move away from religious economics and the influence of religion on economic behavior. This split, according to Paul Oslington, is not good for the field; progress will require "more detailed knowledge of religion and theology" (2011, p. 17). As economists further delve into the field, they are learning that religiosity cannot be measured only by looking at easily quantifiable factors like attendance and that the content of religious thought matters to how it is practiced. These expanded areas of economists' inquiry raise important questions in keeping with the missions of Christian colleges. While an economist could teach such a course alone, it would likely benefit from collaborative work between two professors in order to push the boundaries of the economic way of thinking, which tends to marginalize philosophical questions.

Evidence from our course indicates that it could be highly beneficial in an evangelical college where theologically serious students are looking for ways to incorporate their liberal arts educations into their Christian lives. One of our advanced economics students, for example, used the information learned in this class to write an essay for a contest sponsored by a national Christian denomination addressing the question of whether that denomination should change or not. The student credited this class with providing the information needed to win the essay contest, which included a prize of $\$ 5,000$. Another student with an evangelical background reported regularly taking the material from this class back to church for further discussion in a faith community. Christian colleges that are serious about helping their students to see the complex interactions of all areas of their lives - rather than artificially separating their Sunday morning activities from the things they do the rest of the week — should encourage this sort of interdisciplinary learning.

\section{CONCLUSION}

This course is merely one example of the many ways in which the culture of higher education, including economic pedagogy, is gradually shifting. Effective teaching is no longer a simple matter of passing along information; it is about helping our students to cultivate habits of independent thinking and a commitment to lifelong learning. In economics departments, this may point to a need to engage topics and perspectives we have generally left unexamined, such as religion. While we should not kid ourselves that we can force our students to learn what we hope they learn, there is evidence that choices we make can make a difference; "students are individuals who are influenced by a wide range of experiences and characteristics.... [E]conomics instructors do make pedagogical decisions that help to shape part of these experiences, and these decisions can have a moderate impact on student choices" (Jensen \& Owen, 2001, p. 338). Interdisciplinary inquiry of this sort serves to advance "our understanding of religion's role in societies past, present, and future" (Iannaccone, 2010, p. 9) and is a course that could be highly beneficial to students in Christian liberal arts environments in both the short and long terms.

\section{ENDNOTES}

1 Some economists have continued to have discussions with theologians. While some theologians have suggested that there is a need for a wholesale rethinking of economics and the economy before genuine dialogue can take place (Long et al., 2007), others such as those in a recent symposium in the Faith and Economics Journal have continued to maintain an open stance toward interdisciplinary dialogue (no. 58, Fall 2011).

2 Historians of economics have worked under this assumption for decades. See for example:

Langholm, Odd 2009, "Martin Luther's Doctrine on Trade and Price in Its Literary Context," History of Political Economy, 41: 87-107.

Neves, Joāo Césardas 2000, “Aquinas and Aristotle’s Distinction on Wealth," History of Political Economy, 32: 649-657.

Viner, Jacob 1978, "Chapter Four: Protestantism and the Rise of Capitalism," History of Political Economy, 10: 151-189.

3 For example:

$$
\begin{aligned}
& \text { Presley, John R. \& Sessions, John G. 1994, "Islamic } \\
& \text { Economics: The Emergence of a New Paradigm," The } \\
& \text { Economic Journal, } 104 \text { (424): 584-596. }
\end{aligned}
$$

Kuran, Timur 2003, “The Islamic Commercial Crisis: Institutional Roots of Economic Underdevelopment in the Middle East," The Journal of Economic History, 63 (2): 414-446.

4 Today the economic study of religion has been picked up by numerous scholars and bears many marks of disciplinary legitimacy, including a JEL code, an association (Association for the Study of Religion, Economics \& Culture (ASREC)), and a working paper series (ASREC-theARDA.com working paper series). 
${ }^{5}$ http://www.thearda.com/asrec/conference/ (accessed October 17, 2012).

${ }^{6}$ Although Eliade's theory - and universalizing theories in general - has fallen out of favor with religion scholars in the past two decades, it still provides a useful contrast in the context of a conversation about economics and religion, particularly with regard to human nature.

7 While some researchers in economics are studying economic behavior that departs from full rationality, the scientific study of religion has a paucity of research using the rational choice approach.

8 The homework assignments were taken from the Association of Religion Data Archives (www.thearda.com) where the students familiarized themselves with data tied to religion.

${ }^{9}$ Each group was assigned to present on one of the religious sects in Richard Schaefer and William Zeller, Extraordinary Groups: An Examination of Unconventional Lifestyles (Worth, 2007), with an eye toward the economic behaviors and teachings of the group.

${ }^{10}$ We do not provide statistical analysis for three reasons. Our teaching evaluations are mostly qualitative, a large percentage of our better students left for a Model UN conference during the week the evaluations were conducted, and finally our sample size was too small.

11 This is a typical comment from a student without any economics background.

12 One study found that "students with an external locus-of-control orientation who believe they have little or no control over their environment are less likely to assume personal responsibility for their course performance and are more prone to blame powerful others or outside factors, such as luck or fate, to explain observed outcomes. [... Whereas] students who readily assume self-responsibility for their academic performance and who do not rely on others for their achievements tend to be the better students who earn high grades and who are more likely to express their satisfaction through the SET [student evaluation of teaching] process." See Grimes, Paul W., Millea, Meghan J. \& Woodruff, Thomas W. 2004, "Who's to Blame? Student Evaluation of Teaching and Locus of Control," The Journal of Economic Education, 35 (2): 129-147.

\section{REFERENCES}

Azzi, C. \& Ehrenberg, R. G. (1975). Household Allocation of Time and Church Attendance. Journal of Political Economy, 83 (1): 27-56.
Berger, P. L. (1999). The Desecularization of the World: Resurgent Religion and World Politics Grand Rapids, MI: Wm. B. Eerdmans Publishing Company.

Boyle, D. (2004). Millions. Pathé Distribution, United Kingdom: 98 minutes.

Caviglia-Harris, J. L. (2003). Introducing Undergraduates to Economics in an Interdisciplinary Setting. The Journal of Economic Education, 34 (3): 195-203.

"College Learning for the New Global Century: A Report from the National Leadership Council for Liberal Education and America's Promise', (2007). American Association of Colleges \& Universities, Washington, D.C.

Davis, J. R. (1995). Interdisciplinary Courses and Team Teaching: New Arrangements for Learning, Phoenix: Oryx Press.

Eliade, M. (1959). The Sacred and the Profane, New York: Harcourt Brace Jovanovich.

Evensky, J. (2004). Economics in Context. The Journal of Economic Education, 35 (2): 197-211.

Grimes, P. W., Millea, M. J. \& Woodruff, T. W. (2004). "Who's to Blame? Student Evaluation of Teaching and Locus of Control." The Journal of Economic Education, 35 (2): 129-147.

Iannaccone, L. (1998). Introduction to the Economics of Religion. Journal of Economic Literature, XXXVI: 1465-1496.

Iannaccone, L. R. (2010). The Economics of Religion: Invest Now, Repent Later? Faith \& Economics, (55): 1-10.

Jensen, E. A. \& Owen, A. L. (2001). 'Pedagogy, Gender, and Interest in Economics. The Journal of Economic Education, 32 (4): 323-343.

Jensen, E. J. \& Owen, A. L. (2003). Appealing to Good Students in Introductory Economics. The Journal of Economic Education, 34 (4): 299-325.

Kenny, R. W. (1998). Reinventing Undergraduate Education: A Blueprint for America's Research Universities. The Boyer Commission on Educating Undergraduates in the Research University, Carnegie Foundation for the Advancement of Teaching.

Kuran, T. (2003). The Islamic Commercial Crisis: Institutional Roots of Economic Underdevelopment in the Middle East. The Journal of Economic History, 63 (2): 414-446.

Langholm, O. (2009). Martin Luther's Doctrine on Trade and Price in Its Literary Context. History of Political Economy, 41: 87-107. 
Leet, D. \& Houser, S. (2003). Economics Goes to Hollywood: Using Classic Films and Documentaries to Create an Undergraduate Economics Course. The Journal of Economic Education, 34 (4): 326-332.

Long, D. S., Fox, N. R. \& York, T. (2007). Calculated Futures: Theology, Ethics, and Economics, Waco, TX: Baylor University Press.

Nelson, R. H. (2001). Economics as Religion University Park, PA: Pennsylvania State University Press.

Neves, J. C. (2000). Aquinas and Aristotle's Distinction on Wealth. History of Political Economy, 32: 649-657.

Oslington, P. (2011). The Significance of the Economics of Religion for the Engagement of Economics with Christian Theology. Faith \& Economics, 56 (Fall): 16-19.
Presley, J. R. \& Sessions, J. G. (1994). Islamic Economics: The Emergence of a New Paradigm. The Economic Journal, 104 (424): 584-596.

Shadyac, T. (2003). Bruce Almighty. Universal Pictures: 101 minutes.

Smith, A. (1981) [1776]. An inquiry into the nature and causes of the wealth of nations. Indianapolis, IN: Liberty Fund.

Viner, J. (1978). Chapter Four: Protestantism and the Rise of Capitalism. History of Political Economy, 10: 151-189.

Waterman, A.M.C. (2001). The beginning of 'boundaries': the sudden separation of economics from Christian theology. Economics and Interdisciplinary Exchange, Routledge, London and New York: 41-63.

\section{Appendix: An Abridged Topics and Reading List}

\section{Texts}

- Schaefer and Zeller, Extraordinary Groups: An Examination of Unconventional Life-Styles

- Stark and Finke, Acts of Faith: Explaining the Human Side of Religion

- Stark, The Rise of Christianity: How the Obscure, Marginal Jesus Movement Became the Dominant Religious Force in the Western World in a Few Centuries

- Berger, The Desecularization of the World: Resurgent Religion and World Politics

\section{Course Schedule}

\begin{tabular}{|l|l|}
\hline \multicolumn{1}{|c|}{ Topics } & \multicolumn{1}{c|}{ Readings } \\
\hline What is economics? & $\begin{array}{l}\text { - Waterman, "The Beginning of Boundaries" } \\
\text { - Eliade, The Sacred and the Profane, ch. 1 }\end{array}$ \\
\hline What is religion? & $\begin{array}{l}\text { - Chidester, Authentic Fakes } \\
\text { - Berger, Desecularization of the World }\end{array}$ \\
\hline Religion's continuing relevance & $\begin{array}{l}\text { - Stark \& Finke, "Secularization, R.I.P." (Acts of Faith) } \\
\text { Jenkins, "The Next Christianity" } \\
\text { (www.theatlantic.com/doc/200210/jenkins) }\end{array}$ \\
\hline $\begin{array}{l}\text { Economics of religion: the rational } \\
\text { choice approach }\end{array}$ & $\begin{array}{l}\text { - Iannaccone, "Rational Choice: Framework for the Social Scientific Study } \\
\text { of Religion" "Iannaccone, "Introduction to the Economics of Religion" } \\
\text { Becker, "The Economic Way of Looking at Behavior" }\end{array}$ \\
\hline A General Theory & $\begin{array}{l}\text { - Iannaccone, "The Economics of the Supernatural: A General Theory of } \\
\text { Religion and Magic" }\end{array}$ \\
\hline
\end{tabular}




\begin{tabular}{|c|c|}
\hline $\begin{array}{l}\text { Economics, religion, and the individual } \\
\text { (or, Who is the human being?) }\end{array}$ & $\begin{array}{l}\text { - Iannaccone, "Risk, Rationality, and Religious Portfolios" } \\
\text { - Bentham, Principles of Morals and Legislation (I - II) }\end{array}$ \\
\hline Religious groups and sects & $\begin{array}{l}\text { - Smith, Wealth of Nations (I.1 - I.5) } \\
\text { - Stark \& Finke, "Religious Group Dynamics" } \\
\text { - Stark \& Finke, "Church to Sect Movements" }\end{array}$ \\
\hline $\begin{array}{l}\text { Economics, religion, and institutions: } \\
\text { churches and sects }\end{array}$ & $\begin{array}{l}\text { - Iannaccone, "Why Strict Churches are Strong" } \\
\text { - The Power of the Mustard Seed: Why Strict Churches are Strong } \\
\text { (http://www.slate.com/id/2118313/) }\end{array}$ \\
\hline $\begin{array}{l}\text { Economics, religion, and institutions: } \\
\text { free riders and club goods }\end{array}$ & $\begin{array}{l}\text { - Gary Richardson, "Craft Guilds and Christianity in Late-Medieval Eng- } \\
\text { land: A Rational Choice Analysis." } \\
\text { - McBride et al, "Club Mormon: Free Riders, Monitoring, and Exclusion } \\
\text { in the LDS Church" }\end{array}$ \\
\hline Economics, religion, and the state & $\begin{array}{l}\text { - Iannaccone, Finke, \& Stark, "Deregulating Religion: The Economics of } \\
\text { Church and State" } \\
\text { - Stark \& Finke, "Religious Competition and Commitment" } \\
\text { - "In Europe, God is (Not) Dead" } \\
\text { (online.wsj.com/article/SB118434936941966055.html) }\end{array}$ \\
\hline Opportunity Costs & - Iannaccone, "Religious Practice: A Human Capital Approach" \\
\hline The economics of conversion & $\begin{array}{l}\text { - Stark, "Epidemics, Networks, and Conversion" (The Rise of Christianity) } \\
\text { - Ensminger, "Transaction Costs and Islam: Explaining Conversion in } \\
\text { Africa" }\end{array}$ \\
\hline Financing religion & - Iannaccone and Bose, "Financing of Religion: Theory and Evidence" \\
\hline $\begin{array}{l}\text { Does economics shape religion, or does } \\
\text { religion shape economics? }\end{array}$ & $\begin{array}{l}\text { - Marx, Manifesto of the Communist Party } \\
\text { - Weber, The Protestant Ethic and the Spirit of Capitalism } \\
\text { - Ekelund, Hebert, and Tollison, "An Economic Analysis of the Protestant } \\
\text { Reformation" }\end{array}$ \\
\hline $\begin{array}{l}\text { Reproduction: a religious or an eco- } \\
\text { nomic issue? }\end{array}$ & $\begin{array}{l}\text { - Rector \& Pardue, "Understanding the President's Healthy Marriage } \\
\text { Initiative" } \\
\text { - West, "The Policing of Poor Black Women's Sexual Reproduction" }\end{array}$ \\
\hline $\begin{array}{l}\text { What does economics have to do with } \\
\text { ethics? }\end{array}$ & $\begin{array}{l}\text { - Knight, "Ethics and the Economic Interpretation" } \\
\text { - Blank/McGurn, Is the Market Moral? }\end{array}$ \\
\hline Is economics a religion? & $\begin{array}{l}\text { - Nelson, Economics as Religion } \\
\text { - Nelson, "Scholasticism versus Pietism: The Battle for the Soul of Economics" }\end{array}$ \\
\hline Economics, religion, and terrorism & $\begin{array}{l}\text { - Juergensmeyer, "Soldiers for Christ" } \\
\text { - Lawrence, Messages to the World: The Statements of Osama Bin Laden } \\
\text { - Iannaccone, "The Market for Martyrs" }\end{array}$ \\
\hline Conclusion & - McCloskey, "Avarice, Prudence, and the Bourgeois Virtues" \\
\hline
\end{tabular}




\section{Other Resources}

- www.thearda.com (for extensive materials and data pertaining to religion)

- www.thearda.com/asrec (for more information on the professional association tied to economics of religion)

- http://en.wikipedia.org/wiki/Economics_of_religion (has a lengthy citation list that could be used to develop a course)

- Possible Textbook: The Oxford Handbook of the Economics of Religion, Rachel M. McCleary (Editor), 2011. 